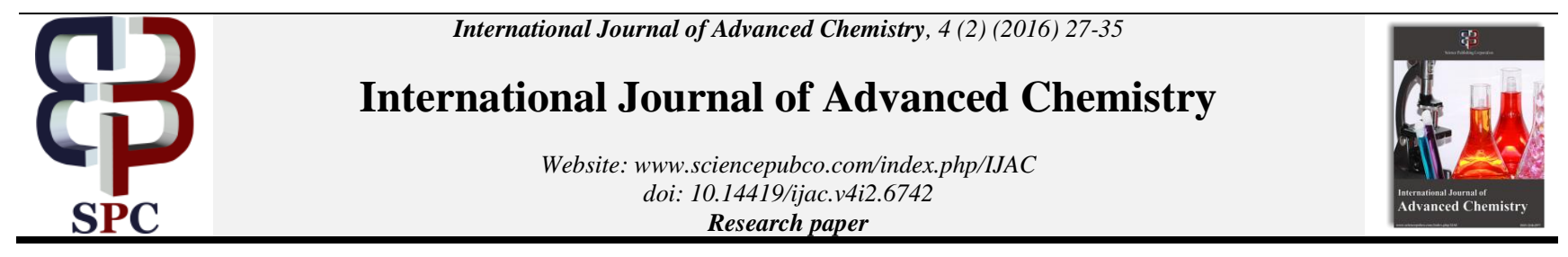

\title{
Synthesis, spectral characterization, molecular structure, HOMO-LUMO, MEP and NLO analysis of some (E)-N-(4-Fluoro-3-Phenoxybenzylidene)- substituted benzenamines
}

\author{
G. Jesu Retna Raj, P. Jayanthi and M. Sekar* \\ Department of Chemistry, Government Arts College, C. Mutlur, Chidambaram - 608102, India \\ *Corresponding author E-mail: drmschemgac@gmail.com
}

\begin{abstract}
In this work, (E)-N-(4-Fluoro-3-Phenoxybenzylidene)-substituted benzenamines (1-6) have been synthesized and characterized by IR, ${ }^{1} \mathrm{H}$ and ${ }^{13} \mathrm{C}$ NMR spectral studies. Density functional theory (DFT) has been used to optimize geometrical parameters, atomic charges, vibrational wavenumbers and intensity of vibrational bands. The molecular properties HOMO-LUMO, MEP and atomic charges of carbon, nitrogen and oxygen were calculated using B3LYP/6-311G $(\mathrm{d}, \mathrm{p})$ basis set. The polarizability and first order hyperpolarizability of the title Compounds were calculated and interpreted.
\end{abstract}

Keywords: DFT; HOMO - LUMO Energies; NLO; MEP; Substituted Benzenamines.

\section{Introduction}

Compounds containing an azomethine group (-CH=N-), known as Schiff bases, are formed by the condensation of a primary amine with a carbonyl compound. Schiff bases of aliphatic aldehydes are relatively unstable which are readily undergoes polymerization while those of aromatic aldehydes having an effective conjugation system are found to be more stable. Schiff bases have been reported to play a very important role in many biological and chemical reactions, due to the presence of the imine linkage. They are facing a growing interest due to their various applications as anticancer (Sinha et al. 2008; Crowe et al. 1980; Wang et al. 2001; Przybylski et al. 2008; Desai et al. 2001), antibacterial (Shivakumar et al. 2008; Przybylski et al. 2009; Pandeya et al. 1999; Karthikeyan et al. 2006), antiviral (Holla et al. 2001; Jarrahpour et al. 2007; da Silva et al. 2011) and antifungal (Singh et al. 1981; Saravanan et al. 2010; Panneerselvam et al. 2005). Intra-molecular hydrogen bonding between $\mathrm{OH}$ hydrogen and $\mathrm{C}=\mathrm{N}$ nitrogen atoms of Schiff bases determines the properties of various molecular systems and plays a significant role in many biochemical mechanisms (Singh et al. 2001). $\mathrm{C}=\mathrm{N}$ linkage in the azomethine derivatives is essential for biological activity (Walsh et al. 1996). The proton transfer is known to be crucial for physicochemical properties and practical application of Schiff bases, this process has been widely studied in literature (Odabasoglu et al. 2007). Schiff bases have been used extensively as ligands for the synthesis of novel organometallic compounds (Vicini et al. 2003; Pandeya et al. 1999). Inspite of these synthetic utility, Schiff bases have good electronic, linear and non-linear optical properties (SzadyChelmieniecka et al. 2001; Dhanaraj et al. 2009; Schilf et al. 2002). Several theoretical analyses have been carried out for isomeric forms of these Schiff bases (Yuan et al. 2000). The present investigation is focused on the synthesis and theoretical investigation of the molecular structures and their vibrational frequencies analysis and charges of newly synthesized Schiff bases derived from 4-Fluoro-3-phenoxybenzaldehyde having extended conjugation. HOMO- LUMO energies, dipole moments, polarizabilities and first hyperpolarizabilities were determined by density functional theory (DFT) method.

\section{Experimental details}

General Procedure for Preparation of (E)-N-(4-Fluoro-3Phenoxybenzylidene)-Substituted Benzenamine.

The Schiff bases were obtained by refluxing equimolar quantities of the substituted aromatic amine, 4-Fluoro-3phenoxybenzaldehyde and few drops of glacial acetic acid, (0.01 mole of each in $25 \mathrm{~mL}$ ethanol) on a water bath for 5-6 hrs. After the completion of the reaction, as monitored by TLC, the resulting solution was cooled to room temperature, and then poured in crushed ice with constant stirring. The precipitate was filtered and washed with cold water. Then this was recrystallized using ethanol to obtain pale yellow solid. The analytical and spectral data of synthesized Schiff bases are presented in Table-1. 
<smiles>[R]c1cccc(N)c1</smiles><smiles>O=Cc1ccc(F)c(Oc2ccccc2)c1</smiles><smiles>[R]c1cccc(N=Cc2ccc(F)c(Oc3ccccc3)c2)c1</smiles>

$\mathrm{R}=4-\mathrm{Cl}$, 4- $\mathrm{Br}, 4-\mathrm{OCH}, 3-\mathrm{NO}_{2}, 4-\mathrm{NO}_{2}, 2-\mathrm{NO}_{2}-4-\mathrm{OCH}_{3}$

Table 1: The Physical Analytical, Melting Point and Spectral Data of (E)-N-(4-Fluoro-3- Phenoxybenzylidene)-Substituted Benzenamines (1-6)

\begin{tabular}{|c|c|c|c|c|c|c|c|c|}
\hline Entry & X & M. F. & M. W. & Yield (\%) & m. p. $\left({ }^{\circ} \mathrm{C}\right)$ & $\begin{array}{l}\mathrm{IR} \\
\mathrm{C}=\mathrm{N}\end{array}$ & $\begin{array}{l}{ }^{1} \mathrm{H} \text { NMR } \\
\mathrm{CH}=\mathrm{N}\end{array}$ & $\begin{array}{l}{ }^{13} \mathrm{C} \text { NMR } \\
\mathrm{C}=\mathrm{N}\end{array}$ \\
\hline 1 & $4-\mathrm{Cl}$ & $\mathrm{C}_{19} \mathrm{H}_{13} \mathrm{ClFNO}$ & 325.8 & 88 & $60-61$ & 1589.34 & 8.353 & 159.22 \\
\hline 2 & $4-\mathrm{Br}$ & $\mathrm{C}_{19} \mathrm{H}_{13} \mathrm{BrFNO}$ & 370.2 & 91 & $63-64$ & 1589.34 & 8.296 & 159.21 \\
\hline 4 & $3-\mathrm{NO}_{2}$ & $\mathrm{C}_{19} \mathrm{H}_{13} \mathrm{FN}_{2} \mathrm{O}_{3}$ & 336.3 & 83 & $81-82$ & 1591.27 & 8.398 & 160.56 \\
\hline 5 & $4-\mathrm{NO}_{2}$ & $\mathrm{C}_{19} \mathrm{H}_{13} \mathrm{FN}_{2} \mathrm{O}_{3}$ & 336.3 & 91 & $96-97$ & 1589.34 & 9.892 & 159.2 \\
\hline 6 & $2-\mathrm{NO}_{2}-4-\mathrm{OCH}_{3}$ & $\mathrm{C}_{20} \mathrm{H}_{15} \mathrm{FN}_{2} \mathrm{O}_{4}$ & 366.1 & 85 & $92-93$ & 1598.99 & 9.887 & 156.09 \\
\hline
\end{tabular}

\subsection{Spectral measurements}

Infrared spectra $\left(\mathrm{KBr}, 4000-400 \mathrm{~cm}^{-1}\right)$ have been recorded on Avatar-330 FT-IR spectrophotometer. The NMR spectra of all synthesized compounds have been recorded on Bruker $400 \mathrm{MHz}$ spectrometer operating at $400 \mathrm{MHz}$ for recording ${ }^{1} \mathrm{H}$ spectra and $100 \mathrm{MHz}$ for ${ }^{13} \mathrm{C}$ spectra in $\mathrm{CDCl}_{3}$ solvent using TMS as internal standard.

\subsection{Computational studies}

All calculations were done at density functional theory (DFT) level on a personal computer using Gaussian-03 package using B3LYP/6-311G (d, p) basis set (Frisch et al. 2004). The polarizabilities and hyperpolarizabilities were determined from the DFT optimized structure by finite field approach using B3LYP/6-311 G $(\mathrm{d}, \mathrm{p})$ basis set. Vibrational frequencies and Mulliken charges have also characterized using the B3LYP/6-311 G $(\mathrm{d}, \mathrm{p})$ available in Gaussian-03 package.

\section{Results and discussion}

\subsection{Molecular geometry}

The optimized structural parameters such as bond lengths, bond angle and dihedral angle of $(1-6)$ were determined at B3LYP level theory with $6-311 \mathrm{G}(\mathrm{d}, \mathrm{p})$ basis set and are presented in Table - 2. Optimized structure of (E)-N-(4-Fluoro-3Phenoxybenzylidene)-substituted benzenamines (1-6) shown in Fig. 1. Overall, the C9-C8-N7 bond angles of compound (1-6) illustrate the double bond character and the $\mathrm{sp}^{2}$ hybridization of the imine carbon atom and the torsion angles [C6-N7-C8-C9 of 177.6] in title compounds, indicate an almost planar Econfiguration with respect to the imine $\mathrm{C}=\mathrm{N}$ bond. As a result from optimized structural parameters such as bond lengths, bond and dihedral angles, we can conclude the E-configuration with respect to the imine $\mathrm{C}=\mathrm{N}$ bond is more stable compound.

\subsection{Mulliken analysis}

The Mulliken atomic charges of synthesized molecules calculated by the same basic set and are tabulated in Table-3. Results from Mulliken charge analysis shows that all the hydrogen atoms have a net positive charge. The obtained atomic charge shows that the $\mathrm{H} 2$ atom has bigger positive atomic charge than the other hydrogen atoms. This is due to the presence of electronegative group. In order to have an easy look at the charge changes a column chart is illustrated as Fig. 2. From Tables-3, we can observed that most of the carbons having negative values compare to $\mathrm{C} 6, \mathrm{C} 8, \mathrm{C} 9, \mathrm{C} 12$, $\mathrm{C} 13, \mathrm{C} 16$. This is due to adjacent electronegative atoms. These data clearly shows that (1-6) are the most reactive towards substitution reactions.

\subsection{Molecular electrostatic potential analysis}

Molecular electrostatic potential (MEP) is a helpful descriptor used to visualize the electrophilic or nucleophilic reactive sites of molecules (Prasad et al. 2010] and to show the electrostatic potential regions in terms of color grading.

In MEP map Fig. 3, different values of the electrostatic potential are represented by different colors: red and blue represents the regions of the most negative and positive electrostatic potential whereas green represents the region of zero potential. Potential increases in the order of: red < orange < yellow < green < blue. The positive regions are placed around all hydrogen atoms, which are related to nucleophilic reactivity (Kavitha et al. 2010). The nitrogen and oxygen atoms in compounds (1-6) exhibit a negative charge, which are donor atoms. From these data we conclude from this our 
title molecules are ready for both electrophilic and nucleophilic reactions.

\subsection{Frontier molecular orbital analysis}

As seen from HOMO-LUMO Fig. 4, in the title compounds (1-6), the electron cloud distribution in HOMO is localized on whole benzene ring, while the LUMO is localized mainly on the azomethine and azomethine side benzene group. The difference of the charge separation between the HOMO and LUMO of those structure play important role in the internal charge transfer (ICT). Furthermore, the difference on the values of $\Delta \mathrm{E}$ of compounds (1-6) was observed, which has different substituent at 1 or 2 or 3- sites of the phenyl core.

For a system having lower value of $\Delta \mathrm{E}$ makes it more reactive or less stable and also has a direct influence on the electron density difference for the stabilizing ICT process. In this sense, it seems that the selection of a compound 6 containing substituent has a beneficial effect among the designed candidate. It may be due to the presence of both electron-donating and electron-withdrawing present in the phenyl core.
As a result, the trend of $\Delta \mathrm{E}$ gap of inspected compounds becomes $6<4<5<3<2<1$. We can observe from HOMO-LUMO Tables, the introduction of different substituent at 1 or 2 or 3- sites of the phenyl core significantly change the $\Delta \mathrm{E}$ value.

Chemical hardness is related with the stability and reactivity of a chemical system, it measures the resistance to change in the electron distribution or charge transfer. In this sense, chemical hardness corresponds to the gap between the HOMO and LUMO. The larger the HOMO-LUMO energy gap, the harder and more stable/less reactive the molecule. The higher value of $\Delta \mathrm{E}$ represents more hardness or less softness of a compound, thus compound 1 referred as hard molecule when compared to 2-6 (Koopmans, 1934). Another global reactivity descriptor electrophilicity index $(\psi)$ describes the electron accepting ability of the systems quite similar to hardness and chemical potential. High values of electrophilicity index increases electron accepting abilities of the molecules. Thus, electron accepting abilities of compounds (1-6) are arranged in following order: $4>6>5>1 \approx 2>3$.

Table 2: Selected Bond Lengths, Bond Angles and Dihedral Angles of (E)-N-(4-Fluoro-3-Phenoxybenzylidene)-Substituted Benzenamines (1-6)

\begin{tabular}{|c|c|c|c|c|c|c|c|}
\hline Bond length $(\AA)$ & $\mathrm{XRD}^{\mathrm{a}}$ & 1 & 2 & 3 & 4 & 5 & 6 \\
\hline $\mathrm{C} 1-\mathrm{C} 2$ & 1.395 & 1.393 & 1.39 & 1.396 & 1.386 & 1.388 & 1.407 \\
\hline $\mathrm{C} 2-\mathrm{C} 3$ & 1.378 & 1.394 & 1.396 & 1.399 & 1.397 & 1.395 & 1.398 \\
\hline $\mathrm{C} 3-\mathrm{Cl} 3$ & & 1.758 & 1.911 & 1.364 & 1.467 & & \\
\hline $\mathrm{C} 3-\mathrm{C} 4$ & & 1.397 & 1.393 & 1.406 & 1.394 & 1.393 & 1.393 \\
\hline $\mathrm{C} 4-\mathrm{C} 5$ & 1.4 & 1.39 & 1.393 & 1.384 & 1.389 & 1.395 & 1.407 \\
\hline C5-C6 & 1.386 & 1.406 & 1.401 & 1.409 & 1.404 & 1.403 & 1.382 \\
\hline C6-N7 & 1.419 & 1.405 & 1.404 & 1.404 & 1.401 & 1.404 & 1.388 \\
\hline $\mathrm{N} 7-\mathrm{C} 8$ & 1.257 & 1.251 & 1.251 & 1.25 & 1.253 & 1.252 & 1.248 \\
\hline C9-C10 & & 1.409 & 1.409 & 1.409 & 1.409 & 1.402 & 1.409 \\
\hline $\mathrm{C} 10-\mathrm{C} 11$ & & 1.39 & 1.39 & 1.39 & 1.39 & 1.394 & 1.39 \\
\hline C11-C12 & & 1.39 & 1.391 & 1.391 & 1.39 & 1.385 & 1.391 \\
\hline $\mathrm{C} 12-\mathrm{C} 13$ & & 1.391 & 1.401 & 1.4 & 1.403 & 1.408 & 1.402 \\
\hline $\mathrm{C} 12-\mathrm{F} 12$ & & 1.342 & 1.342 & 1.343 & 1.341 & 1.342 & 1.342 \\
\hline C13-C14 & & 1.393 & 1.393 & 1.394 & 1.393 & 1.389 & 1.393 \\
\hline C14-O15 & & 1.371 & 1.371 & 1.373 & 1.369 & 1.369 & 1.372 \\
\hline $\mathrm{O} 15-\mathrm{C} 16$ & & 1.387 & 1.387 & 1.385 & 1.389 & 1.393 & 1.387 \\
\hline C17-C18 & & 1.395 & 1.395 & 1.394 & 1.395 & 1.396 & 1.395 \\
\hline C18-C19 & & 1.396 & 1.396 & 1.396 & 1.397 & 1.396 & 1.396 \\
\hline $\mathrm{C} 19-\mathrm{C} 20$ & & 1.396 & 1.396 & 1.396 & 1.396 & 1.396 & 1.396 \\
\hline C20-C21 & & 1.395 & 1.395 & 1.395 & 1.395 & 1.396 & 1.395 \\
\hline C21-C16 & & 1.397 & 1.395 & 1.397 & 1.394 & 1.394 & 1.395 \\
\hline \multicolumn{8}{|l|}{ Bond angle $\left({ }^{\circ}\right)$} \\
\hline C1-C6-N7 & 118.8 & 123.2 & 123.2 & 123.3 & 123.1 & 123 & 121.3 \\
\hline C9-C8-N7 & 122.6 & 127.6 & 127.6 & 127.9 & 127.3 & 127.6 & 121.8 \\
\hline C6-N7-C8 & 117.8 & 127.8 & 127.8 & 128.3 & 127.4 & 127.1 & 130 \\
\hline C8-C9-C10 & 122.2 & 121.6 & 121.6 & 121.7 & 121.5 & 120.9 & 121 \\
\hline C8-C9-C14 & 119.2 & 118.7 & 118.7 & 118.8 & 118.7 & 119.1 & 119 \\
\hline C12-C13-O15 & & 116.8 & 116.8 & 117.1 & 116.5 & 115.7 & 116.8 \\
\hline C14-C13-O15 & & 124.5 & 124.5 & 124 & 124.9 & 125.7 & 124.4 \\
\hline F12-C12-C13 & & 118.7 & 118.7 & 118.9 & 118.6 & 118.3 & 118.6 \\
\hline C17-C16-O15 & & 116.7 & 116.7 & 116.2 & 121.7 & 119.3 & 116.6 \\
\hline C21-C16-C15 & & 122.2 & 122.2 & 122.8 & 117 & 119.3 & 122.3 \\
\hline \multicolumn{8}{|l|}{ Dihedral $\left({ }^{\circ}\right)$} \\
\hline C10-C9-C8-N7 & 0.2 & 0.7 & 0.8 & 0.3 & 0.8 & 0.1 & 14.1 \\
\hline C8-N7-C6-C1 & 0.6 & 0.6 & 0.7 & -0.4 & 1.8 & 0.5 & 4 \\
\hline H8-C8-N7-C6 & 4 & 0.2 & 0.2 & 0.1 & 0.5 & 0.8 & 0.4 \\
\hline H8-C8-C9-C10 & -131 & -179.3 & -179.2 & -179.7 & -179.2 & -170 & -165.9 \\
\hline $\mathrm{H} 8-\mathrm{C} 8-\mathrm{C} 9-\mathrm{C} 14$ & -49 & 0.3 & 0.3 & -0.3 & 0.4 & 0.5 & 12.1 \\
\hline
\end{tabular}




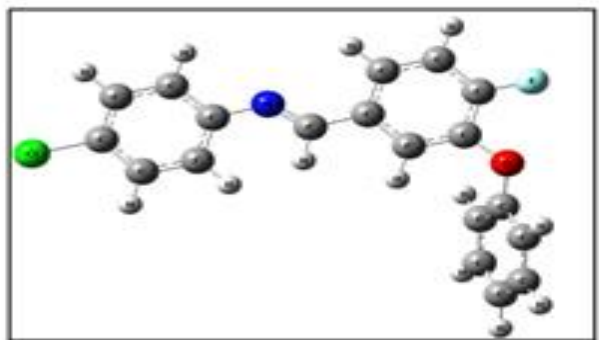

(1)

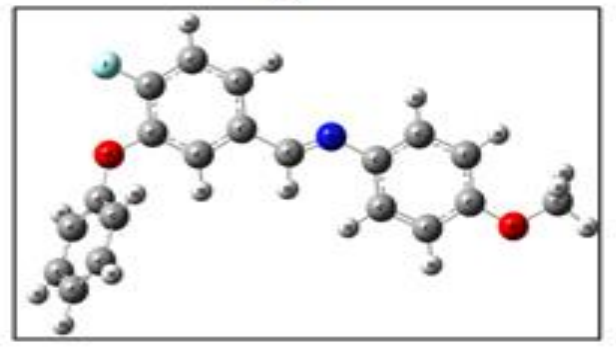

(3)

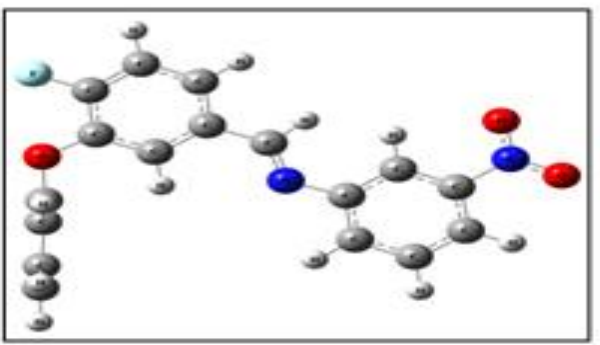

(5)

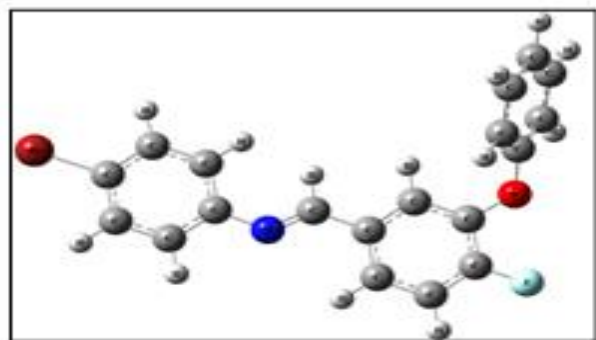

(2)

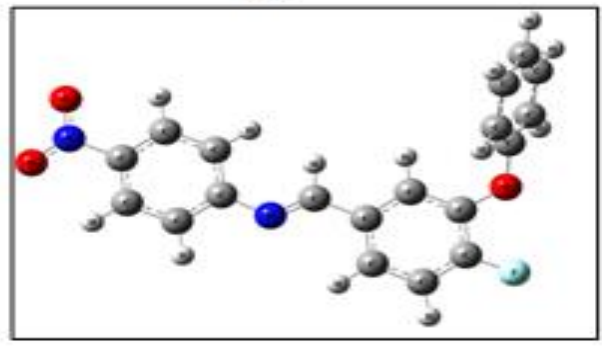

(4)

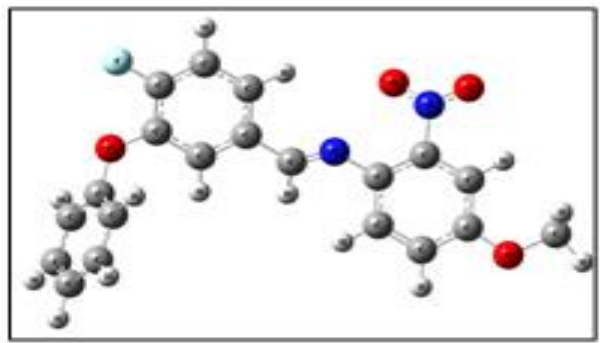

(6)

Fig. 1: Optimized Structureof (E) - N - (4 - Fluoro - 3 - Phenoxybenzylidene $)$ - Substituted Benzenamines (1 - 6).

Table 3: Mulliken Atomic Charges of (E)-N-(4-Fluoro-3-Phenoxybenzylidene)-Substituted Benzenamines (1-6)

\begin{tabular}{|c|c|c|c|c|c|c|c|c|c|c|}
\hline \multirow[t]{2}{*}{ Atom } & \multicolumn{2}{|c|}{ Atom Charge (a. u) } & \multirow[t]{2}{*}{ Atom } & \multirow{2}{*}{$\begin{array}{l}\text { Atom } \\
\text { Charge (a. } \\
\text { u) } \\
3\end{array}$} & \multirow[t]{2}{*}{ Atom } & \multirow{2}{*}{$\begin{array}{l}\text { Atom } \\
\text { Charge (a. } \\
\text { u) } \\
4\end{array}$} & \multirow[t]{2}{*}{ Atom } & \multirow{2}{*}{$\begin{array}{l}\text { Atom } \\
\text { Charge (a. } \\
\text { u) } \\
5 \\
\end{array}$} & \multirow[t]{2}{*}{ Atom } & \multirow{2}{*}{$\begin{array}{l}\text { Atom } \\
\text { Charge (a. } \\
\text { u) } \\
6 \\
\end{array}$} \\
\hline & 1 & 2 & & & & & & & & \\
\hline H1 & 0.103 & 0.104 & H1 & 0.094 & $\mathrm{H} 1$ & 0.109 & H1 & 0.141 & N1 & 0.357 \\
\hline $\mathrm{C} 2$ & -0.077 & -0.107 & $\mathrm{C} 2$ & -0.14 & $\mathrm{C} 2$ & -0.108 & $\mathrm{C} 2$ & 0.223 & $\mathrm{O} 1$ & -0.379 \\
\hline $\mathrm{H} 2$ & 0.113 & 0.112 & $\mathrm{H} 2$ & 0.088 & $\mathrm{H} 2$ & 0.14 & $\mathrm{~N} 2$ & 0.392 & $\mathrm{O} 1$ & -0.4 \\
\hline $\mathrm{C} 3$ & -0.091 & 0.056 & $\mathrm{C} 3$ & 0.356 & $\mathrm{C} 3$ & 0.25 & $\mathrm{O} 2$ & -0.396 & $\mathrm{C} 2$ & -0.147 \\
\hline $\mathrm{Cl}$ & -0.21 & -0.128 & $\mathrm{O} 3$ & -0.516 & N3 & 0.384 & $\mathrm{O} 2^{\prime}$ & -0.396 & $\mathrm{H} 2$ & 0.136 \\
\hline $\mathrm{C} 4$ & -0.089 & -0.095 & $\mathrm{C} 3$ & 0.192 & $\mathrm{O} 3$ & -0.4 & $\mathrm{C} 3$ & -0.089 & $\mathrm{C} 3$ & 0.353 \\
\hline $\mathrm{C} 5$ & -0.07 & -0.092 & $\mathrm{C} 4$ & -0.133 & $\mathrm{O} 3$ & -0.4 & $\mathrm{H} 3$ & 0.137 & $\mathrm{O} 3$ & -0.51 \\
\hline C6 & 0.258 & 0.261 & $\mathrm{C} 5$ & -0.078 & $\mathrm{C} 4$ & -0.094 & $\mathrm{C} 4$ & -0.102 & C3 & -0.087 \\
\hline N7 & -0.485 & -0.486 & C6 & 0.254 & $\mathrm{C} 5$ & -0.108 & $\mathrm{C} 5$ & -0.073 & $\mathrm{C} 4$ & -0.105 \\
\hline $\mathrm{C} 8$ & 0.142 & 0.143 & N7 & -0.484 & C6 & 0.282 & C6 & 0.253 & C5 & -0.092 \\
\hline $\mathrm{C} 9$ & 0.032 & 0.032 & $\mathrm{C} 8$ & 0.13 & N7 & -0.491 & N7 & -0.494 & C6 & 0.261 \\
\hline $\mathrm{C} 10$ & -0.085 & -0.085 & C9 & 0.035 & $\mathrm{C} 8$ & 0.156 & $\mathrm{C} 8$ & 0.155 & N7 & -0.44 \\
\hline $\mathrm{C} 11$ & -0.48 & -0.148 & $\mathrm{C} 10$ & -0.086 & C9 & 0.027 & C9 & 0.027 & $\mathrm{C} 8$ & 0.13 \\
\hline $\mathrm{C} 12$ & 0.328 & 0.328 & C11 & -0.149 & $\mathrm{C} 10$ & -0.082 & $\mathrm{C} 10$ & -0.092 & $\mathrm{C} 9$ & 0.025 \\
\hline F12 & -0.275 & -0.275 & $\mathrm{C} 12$ & 0.326 & C11 & -0.147 & $\mathrm{C} 11$ & -0.151 & $\mathrm{C} 10$ & -0.088 \\
\hline C13 & 0.267 & 0.267 & F12 & -0.278 & $\mathrm{C} 12$ & 0.331 & $\mathrm{C} 12$ & 0.335 & $\mathrm{C} 11$ & -0.148 \\
\hline C14 & -0.117 & -0.117 & C13 & 0.262 & F12 & -0.272 & F12 & -0.274 & $\mathrm{C} 12$ & 0.328 \\
\hline O15 & -0.567 & -0.567 & C14 & -0.116 & C13 & 0.27 & $\mathrm{C} 13$ & 0.28 & F12 & -0.275 \\
\hline $\mathrm{C} 16$ & 0.309 & 0.309 & O15 & -0.568 & C14 & -0.117 & $\mathrm{C} 14$ & -0.122 & $\mathrm{C} 13$ & 0.266 \\
\hline
\end{tabular}




\begin{tabular}{|c|c|c|c|c|c|c|c|c|c|c|}
\hline $\mathrm{C} 17$ & -0.11 & -0.11 & C16 & 0.315 & O15 & -0.566 & O15 & -0.569 & C14 & -0.117 \\
\hline C18 & -0.094 & -0.094 & $\mathrm{C} 17$ & -0.105 & C16 & 0.304 & $\mathrm{C} 16$ & 0.29 & O15 & -0.567 \\
\hline C19 & -0.082 & -0.082 & $\mathrm{C} 18$ & -0.095 & C17 & -0.098 & C17 & -0.9 & C16 & 0.31 \\
\hline $\mathrm{C} 20$ & -0.095 & -0.095 & C19 & -0.084 & $\mathrm{C} 18$ & -0.095 & C18 & -0.096 & $\mathrm{C} 17$ & -0.102 \\
\hline \multirow[t]{4}{*}{$\mathrm{C} 21$} & -0.095 & -0.101 & $\mathrm{C} 20$ & -0.093 & C19 & -0.081 & C19 & -0.078 & $\mathrm{C} 18$ & -0.095 \\
\hline & & & $\mathrm{C} 21$ & -0.112 & $\mathrm{C} 20$ & -0.094 & $\mathrm{C} 20$ & -0.096 & C19 & -0.083 \\
\hline & & & & & $\mathrm{C} 21$ & -0.108 & $\mathrm{C} 21$ & -0.09 & $\mathrm{C} 20$ & -0.093 \\
\hline & & & & & & & & & $\mathrm{C} 21$ & -0.11 \\
\hline
\end{tabular}

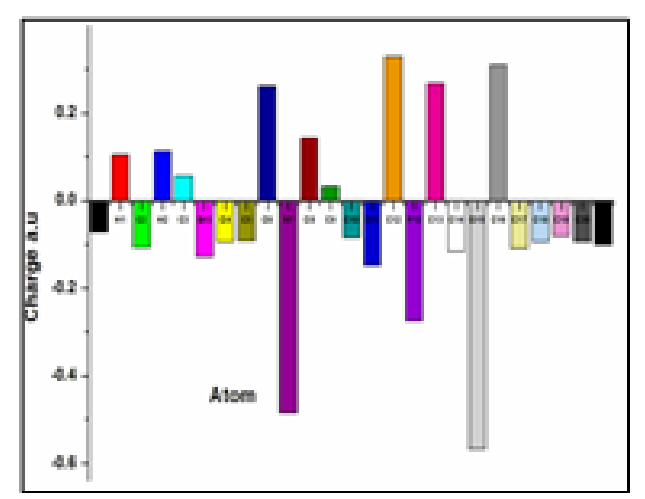

(1)

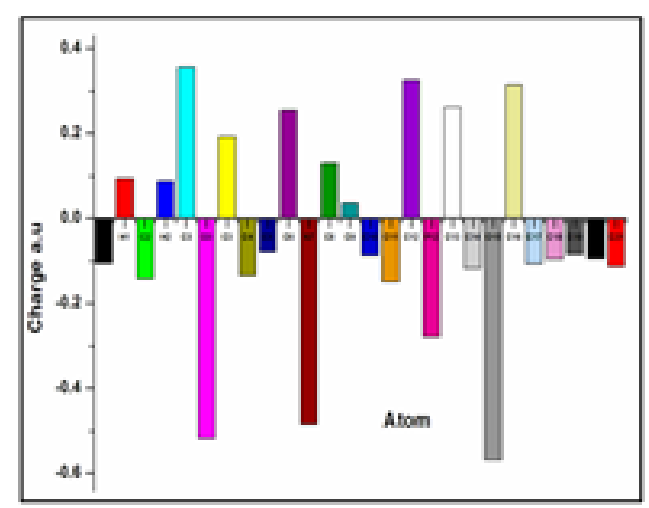

(3)

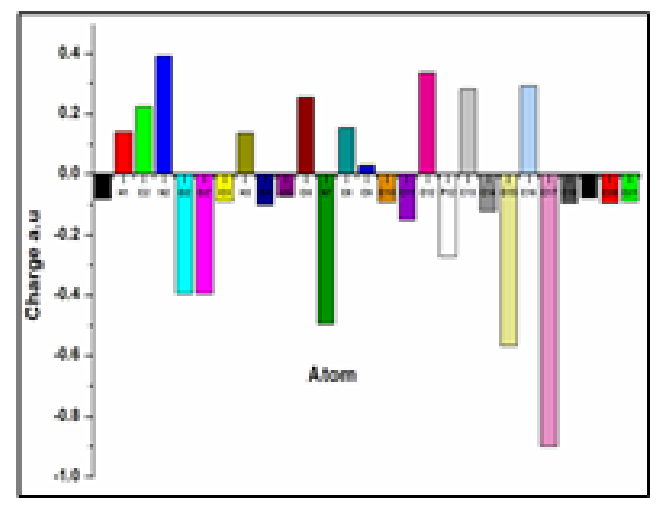

(5)

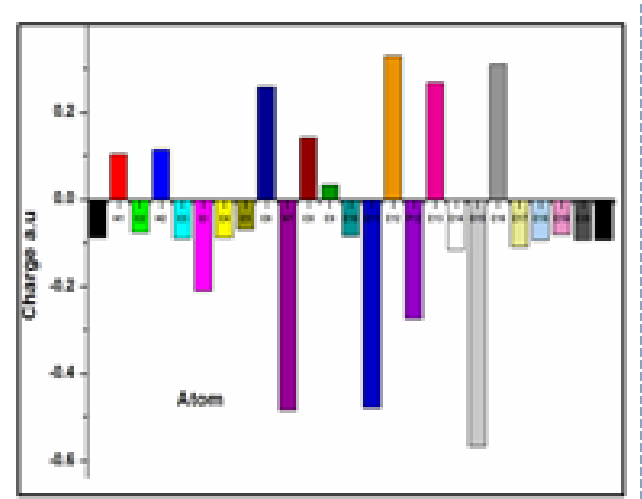

(2)

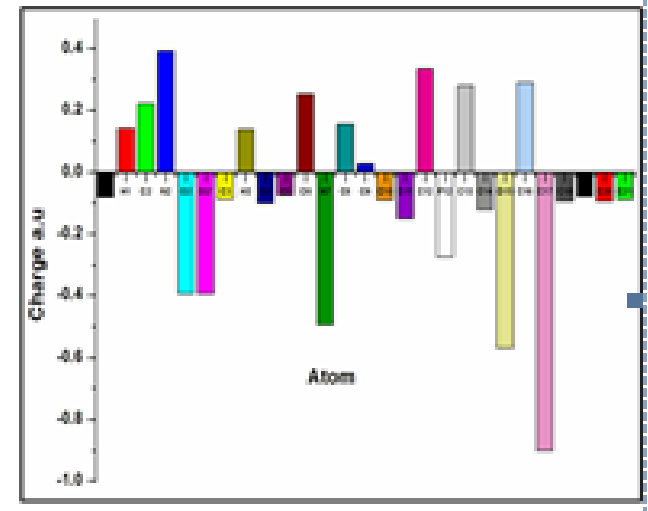

(4)

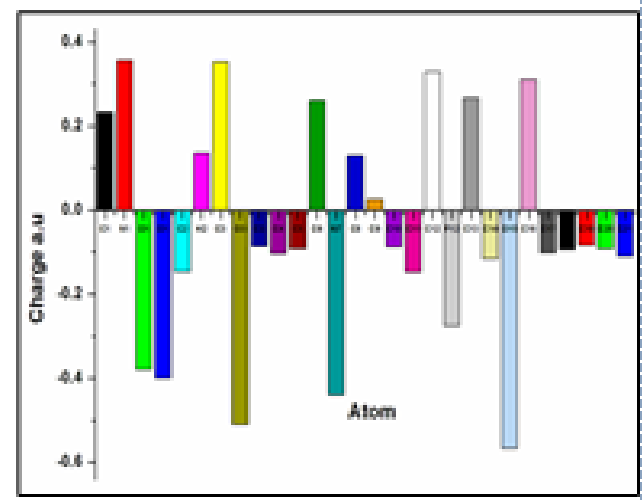

(6)

Fig. 2: Mulliken Charges of (E) - N - (4 - Fluoro - 3 - Phenoxybenzylidene) - Substituted Benzenamines (1 - 6). 


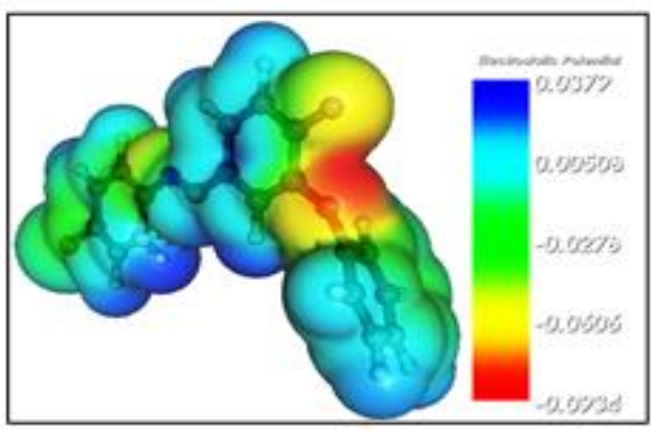

(1)

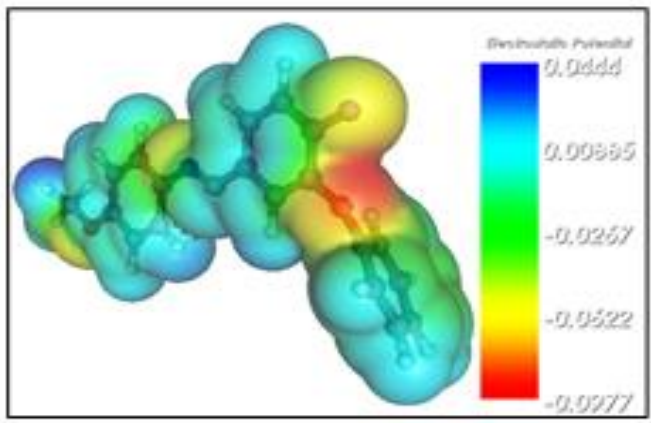

(3)

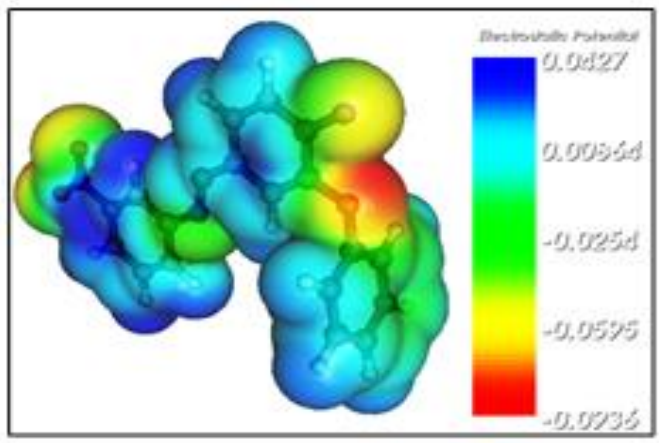

(5)

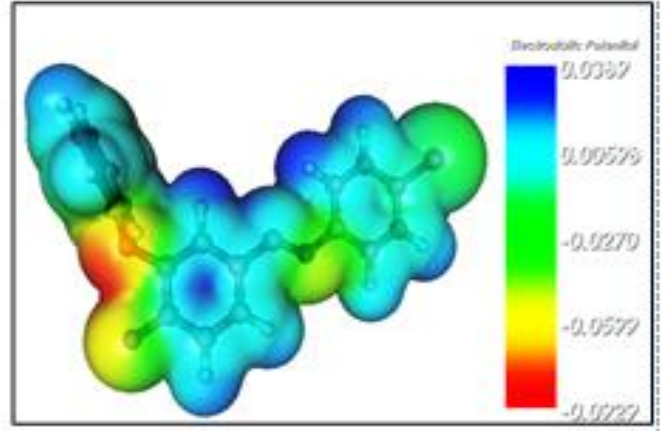

(2)

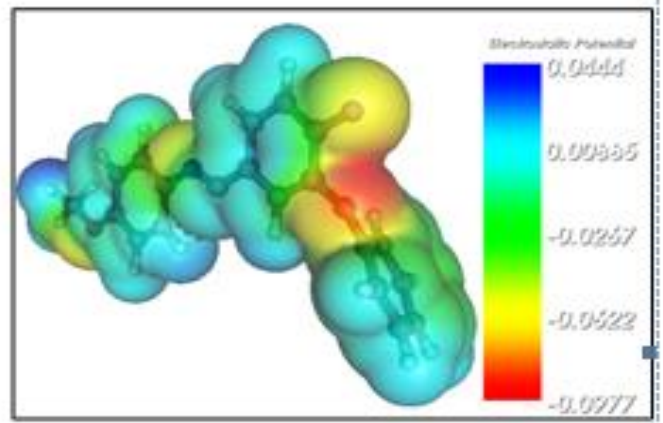

(4)

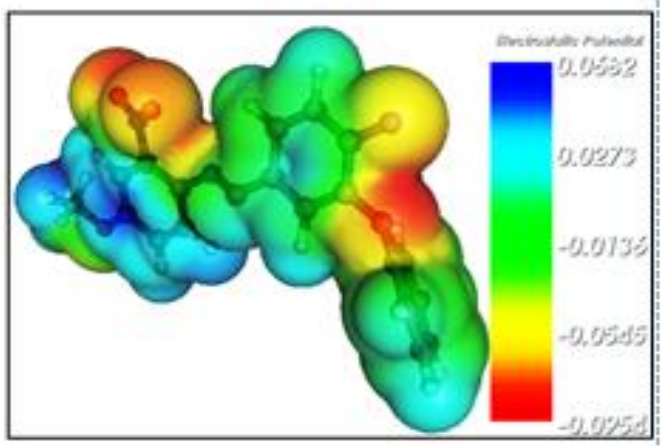

(6)

Fig. 3: Molecular electrostatic Potential Diagrams of (E) - N - (4 - Fluoro - 3 - Phenoxybenzylidene $)$ - Substituted Benzenamines $(1-6)$.

Table 4: Calculated Energy Values (EV) of (E)-N-(4-Fluoro-3-Phenoxybenzylidene)-Substituted Benzenamines (1-6) In Gas Phase

\begin{tabular}{|c|c|c|c|c|c|c|}
\hline B3LYP / 6-311 G(d,p) & 1 & 2 & 3 & 4 & 5 & 6 \\
\hline $\mathrm{E}_{\text {номо }}$ & -6.05 & -6.03 & -5.56 & -6.38 & -6.36 & -6.04 \\
\hline $\mathrm{E}_{\text {LUOMO }}$ & -1.84 & -1.84 & -1.56 & -2.59 & -2.39 & -2.41 \\
\hline ЕLUMO-Номо & 4.21 & 4.19 & 4 & 3.78 & 3.97 & 3.63 \\
\hline $\mathrm{E}_{\text {номо-1 }}$ & -6.37 & -6.35 & -6.12 & -6.75 & -6.86 & -6.33 \\
\hline $\mathrm{E}_{\text {LUомо }+1}$ & -1.75 & -1.75 & -1.41 & -2.14 & -2.01 & -1.85 \\
\hline $\mathrm{E}_{(\mathrm{LUMO}+1)-(\text { НОмО-1) }}$ & 4.62 & 4.6 & 4.71 & 4.6 & 4.85 & 4.48 \\
\hline $\operatorname{Electrinegativity}(\chi)$ & -3.95 & -3.94 & -3.56 & -4.49 & -4.38 & -4.22 \\
\hline Hardness $(\eta)$ & 2.11 & 2.09 & 2 & 1.89 & 1.99 & 1.82 \\
\hline Electrophilicity index $(\psi)$ & 3.7 & 3.7 & 3.16 & 5.32 & 4.82 & 4.91 \\
\hline Softness(s) & 175.79 & 176.88 & 184.98 & 195.64 & 186.29 & 203.85 \\
\hline
\end{tabular}




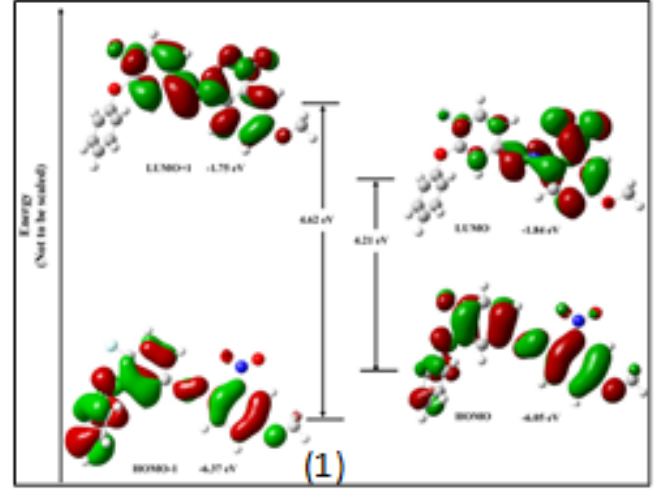

(1)

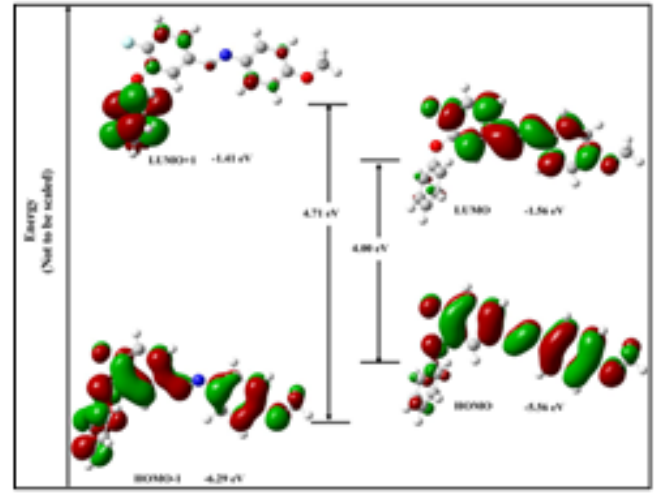

(3)

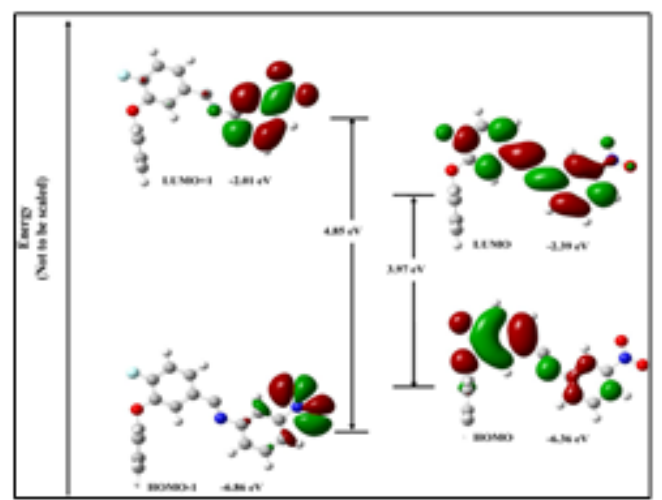

(5)

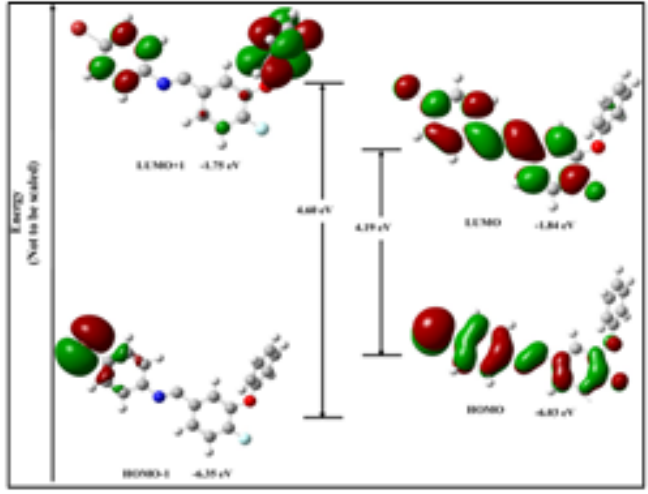

(2)

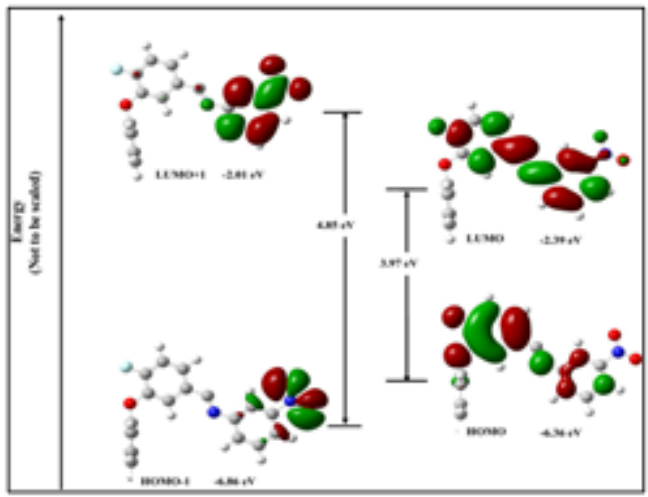

(4)

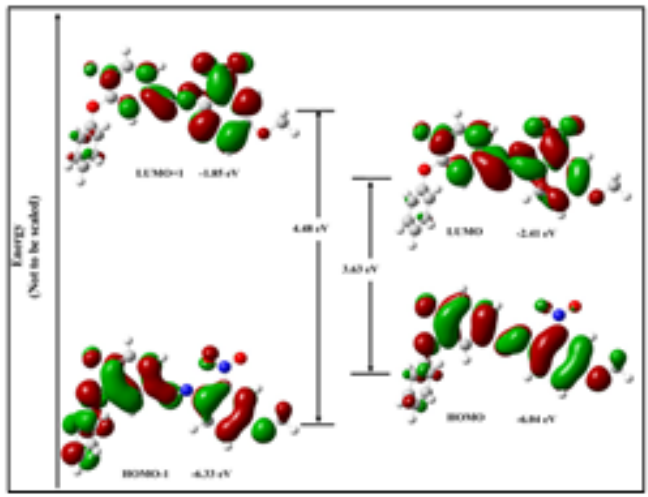

(6)

Fig. 4: Molecular Orvitals and Energies for the HOMO and LUMO in Gas Phase (1 - 6)

\subsection{Non-linear optical activity}

NLO is important property providing key for areas such as telecommunications, signal processing and optical interactions (Arockia doss et al. 2015; Arockia doss et al. 2015). A large variety of NLO switches exhibiting large changes in the first order hyperpolarizability $(\beta)$, the molecular second-order NLO response. In this context, the design of NLO switches, that is, molecules computed for their first hyperpolarizability by alternate their substitution at 1 or 2 or 3 - sites in phenyl core.

From Tables-5, the order of dipole moments for 1-6 is $5>4>6>$ $3>1>2$. The dipole moment in a molecule is an important property that is mainly used to study the intermolecular interactions involving the non-bonded type dipole-dipole interactions. Polarizability is proportional with molecular volume. The bigger molecular polarizability means the more interaction with the electric field of light. Thus, molecular electronic charge distributions have been rearranged by interaction with electric field of light.
As the results mentioned previously, similar derivatives may have significance nonlinear optical property. In this sense a series of new molecules possessing nonlinear optical property are designed which includes $\mathrm{Cl}, \mathrm{Br}, \mathrm{NO}_{2}$, and $\mathrm{OCH}_{3}$ groups at 1 or 2 or 3 - sites of the phenyl core. According to hyperpolarizability tables, all values of each mentioned molecules are greater than their urea values. Therefore, NLO properties of our compounds are better than urea. Results from Tables, the general ranking of NLO properties should be as follows: $4>5>3>2>6>1$. With results in hand, molecule 5 is the best candidate for NLO properties.

To sum up, it can be concluded that the presence of an electron withdrawing group (nitro) in the Meta position at the phenyl ring contributes to decrease the dipole moments, mean polarizability and first order hyperpolarizability of the (1-6) probably because of an inductive competition between the nitro group and the electronic density available in the molecule. The above results show that (1-6) can be best material for NLO applications. 
Table 5: Non-Linear Optical Properties of (1-6) Calculated Using B3LYP Method Using 6-311G (D, P) Basis Set

\begin{tabular}{|c|c|c|c|c|c|c|}
\hline NLO behavior & 1 & 2 & 3 & 4 & 5 & 6 \\
\hline Dipole moment $(\mu) \mathrm{D}$ & 1.447 & 1.384 & 2.672 & 4.989 & 5.06 & 4.918 \\
\hline $\begin{array}{l}\text { Mean polarizability } \\
(\alpha) \times 10^{-23} \mathrm{esu}\end{array}$ & 2 & 2.1 & 1.9 & 2.2 & 2.2 & 2.1 \\
\hline $\begin{array}{l}\text { Anisotropy of the } \\
\text { Polarizability }(\Delta \alpha) \\
\text { x10-24 esu }\end{array}$ & 4.75 & 4.19 & 4.67 & 9.81 & 6.75 & 2.89 \\
\hline $\begin{array}{l}\text { First order polariza- } \\
\text { bility }\left(\beta_{0}\right) \times 10^{-30} \mathrm{esu}\end{array}$ & 1.03 & 2.13 & 2.19 & 3.62 & 2.25 & 2.11 \\
\hline
\end{tabular}

\section{Conclusions}

Structures of (E)-N-(4-Fluoro-3-Phenoxybenzylidene)substituted benzenamines (1-6) were analyzed by $\mathrm{IR},{ }^{1 \mathrm{H}}$ and ${ }^{13} \mathrm{C}$ NMR spectroscopy. In addition, molecular geometry and Mulliken charge analysis predicts the most reactive parts in the molecule. The electronic transitions and states were investigated computationally and show good agreement with the experimental data. The calculated HOMO and LUMO energies were used to analyze the charge transfer within the molecule. The calculated dipole moment and first order hyperpolarizability results indicate that the molecule has a reasonably good nonlinear optical behavior.

\section{Acknowledgement}

The authors thank DST NMR facility, Department of Chemistry, Annamalai University, Annamalainagar-608 002, for recording NMR spectra of all compounds.

\section{References}

[1] Sinha, D., Tiwari, A.K., Singh, S., Shukla, G., Mishra, P., Chandra H., and Mishra, A.K., 2008, Synthesis, characterization and biological activity of Schiff base analogues of indole-3-carboxaldehyde, Eur. J. Med. Chem,. 43, $160 \quad-165$ https://doi.org/10.1016/j.ejmech.2007.03.022.

[2] Crowe, A. J., Smith, P.J. and Atassi, G., 1980, Investigations into the antitumour activity of organotin compounds. I. Diorganotin dihalide and di-pseudohalide complexes Chem. Biol. Interact., 32, 171 - 178. https://doi.org/10.1016/0009-2797(80)90075-7.

[3] Wang, M., Wang, L.F., Li, Y.Z., Li, Q.X., Xu , Z.D. and Qu, D.M 2001, Antitumour activity of transition metal complexes with the thiosemicarbazone derived from 3-acetylumbelliferone, Transit. Met.Chem., 26, 307 https://doi.org/10.1023/A:1007159301849.

[4] Przybylski, P., Pyta, K., Wicher, B., Gdaniec, M., and Brzezinsk, B., 2008, Structure of a new Schiff base of gossypol with 1-(3aminopropyl)-2-pyrrolidinone studied by the X-ray, FT-IR, NMR, ESI-MS and PM5 methods, J. Mol. Struct., 889, 332 - 343. https://doi.org/10.1016/j.molstruc.2008.02.028.

[5] Desai, S.B., Desai, P.B. and Desai, K.R., 2001, Synthesis of some schiff bases,thiazolidinones and azetidinones derived from 2,6diaminobenzo[1,2-d:4,5-d'] bisthiazole and their anticancer activities, Heterocycl. Commun, 7, 83- 90. https://doi.org/10.1515/HC.2001.7.1.83.

[6] Shivakumar, K., Shashidhar, P., Vithalreddy , Halli, M. B., 2008, Synthesis, Spectral Characterization and biological activity of benzofuran Schiff bases with $\mathrm{Co}(\mathrm{II}), \mathrm{Ni}(\mathrm{II}), \mathrm{Cu}(\mathrm{II}), \mathrm{Zn}(\mathrm{II}), \mathrm{Cd}(\mathrm{II})$ and $\mathrm{Hg}(\mathrm{II})$ Complexes, J. Coord Chem , 61(14), 2274-2287. https://doi.org/10.1080/00958970801905239.

[7] Przybylski, P., Huczynski, A., Pyta, K., Brzezinski, B., and Bartl, F., 2009, Biological Properties of Schiff Bases and Azo Derivatives of Phenols, Curr. Org. Chem., 13, $124 \quad$ - 148. https://doi.org/10.2174/138527209787193774.

[8] Pandeya, S.N., Sriram, D., Nath, G., and DeClercq, E., 1999, Synthesis, antibacterial, antifungal and anti-HIV evaluation of Schiff and Mannich bases of isatin derivatives with 3-amino-2methylmercapto quinazolin-4(3H)-one, Pharm. Acta Helv., 74, 1117. https://doi.org/10.1016/S0031-6865(99)00010-2.

[9] Karthikeyan, M.S., Parsad, D.J., Poojary, B., Bhat, K.S., Holla B.S. and Kumari, N.S., 2006, Synthesis and biological activity of Schiff and Mannich bases bearing 2,4-dichloro-5-fluorophenyl moiety, Bioorg.Med. Chem., 14, 7482 https://doi.org/10.1016/j.bmc.2006.07.015.

[10] Holla, B.S., Akberali, P.M., and Shivananda, M.K., 2001, Studies on nitrophenylfuran derivatives Part XII. Synthesis, characterization, antibacterial and antiviral activities of some nitrophenylfurfurylidene-1, 2, 4-triazolo [3, 4-b]-1, 3, 4-thiadiazines, Il Farmaco. 56, 919 - 927. https://doi.org/10.1016/S0014-827X(01)01124-7.

[11] Jarrahpour, A., Khalili, D., De Clercq, E., Salmi, C., and Brune,1 J.M., 2007, Synthesis, Antibacterial, Antifungal and Antiviral Activity Evaluation of Some New bis-Schiff Bases of Isatin and Their Derivatives, $\quad$ Molecules., $\quad 12, \quad 1720 \quad-\quad 1730$. https://doi.org/10.3390/12081720.

[12] da Silva, C.M., da Silva, D.L., Modolo, L.V., Alves, R.B., de Resende, M.A., Martins, C.V.B. and de Fatima, A., 2011, Schiff bases: A short review of their antimicrobial activities, J. Adv. Res. in press, https://doi.org/10.1016/j.jare.2010.05.004.

[13] Singh, H., Yadav, L.D.S., and Mishra, S.B.S., 1981, Studies on some antifungal transition metal chelates of $\mathrm{N}$-(5-phenyl-1, 3, 4thiadiazol-2-yl) dithiocarbamic acid, J. Inorg. Nucl.Chem., 43, 1701 - 1704. https://doi.org/10.1016/0022-1902(81)80367-3.

[14] Saravanan, G., Pannerselvam, P. and Prakash, C.R., 2010, Synthesis and anti-microbial screening of novel schiff bases of 3-amino-2 methyl quinazolin 4-(3H)-one, J. Adv. Pharm. Techn., Res. 1, 320 325.

[15] Panneerselvam, P., Nair, R.R., Vijayalakshmi, G., Subramanian, E.H. and Sridhar, S.K., 2005, Synthesis of Schiff bases of 4-(4aminophenyl)-morpholine as potential antimicrobial agents, Eur.

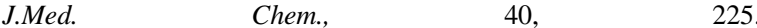
https://doi.org/10.1016/i.ejmech.2004.09.003.

[16] Singh, N.K., and Singh, S.B., 2001, Synthesis characterization and biological properties of manganese (II), cobalt(II), nickel (II), copper(II), zinc(II), chromium(III) and iron(III) compiexes with a new thiosemicarbazide derivative, Indian J. Chem. 40A, 1070 - 1075.

[17] Walsh, O.M., Meegan, M.J., Prendergast, R.M., and Nakib, T.A., 1996, Synthesis of 3-acetoxyazetidin-2-ones and 3hydroxyazetidin-2-ones with antifungal and antibacterial activity, Eur. J. Med. Chem., 31, 989 - 1000. https://doi.org/10.1016/S02235234(97)86178-8.

[18] Odabasoglu, M., Arslan, F., Ölmez, H., and Büyükgüngör, O., 2007, Synthesis, crystal structures and spectral characterization of trans-bisaquabis(o-vanillinato)copper(II), cis-aquabis(ovanillinato)copper(II) and aqua[bis(o-vanillinato)-1,2ethylenediimin]copper(II) , Dyes and Pigments., 75, 507 - 515. https://doi.org/10.1016/j.dyepig.2006.06.033.

[19] Vicini, P., Geronikaki, A., Incerti, M., Busonera, B., Poni, G., Cabras, C.A., and Colla, P.L., 2003, Synthesis and biological evaluation of benzo[d]isothiazole, benzothiazole and thiazole Schiff bases, Bioorg.Med. Chem., 11, 4785 - 4789. https://doi.org/10.1016/S0968-0896(03)00493-0.

[20] Pandeya, S.N., Sriram, D., Nath, G. and DeClercq, E., 1999, Syn thesis, antibacterial, antifungal and anti-HIV activities of Schiff and Mannich bases derived from isatin derivatives and N-[4-(4'chlorophenyl) thiazol-2-yl] thiosemicarbazide, Eur. J. Pharm. Sci., 9, 25 - 31. https://doi.org/10.1016/S0928-0987(99)00038-X

[21] Szady-Chelmieniecka, A., Grech, E., Rozwadowski, Z ., Dziembowska,T., ,.Schilf, W., and Kamienski, B., 2001, Multinuclear NMR study of the intramolecular hydrogen bond in SchiffMannich bases, J. Mol. Struct., 565, 125- 128. https://doi.org/10.1016/S0022-2860(00)00788-2.

[22] Dhanaraj, C.J. and Nair, M.S., 2009, Synthesis, characterization, and antimicrobial studies of some Schiff-base metal(II) complexes, J. Co ord. Chem., 62, $4018 \quad$ - 4028. https://doi.org/10.1080/00958970903191142.

[23] Schilf, W., Kamienski, B., and Dziembowska, T., 2002, Intramolecular hydrogen bond investigations in Schiff bases derivatives of 2-hydroxy-1-naphthaldehyde and 2-hydroxy-1-acetonaphthone in $\mathrm{CDCl} 3$ solution and in the solid state by NMR methods. J. Mol. Struct., 602, 41- 47. https://doi.org/10.1016/S0022-2860(01)007426.

[24] Yuan, H., Graefenstein, J., Kraka, E., and Cremer, D., 2000, What correlation effects are covered by density functional theory?, Molecular Physics., 98:20 1639 - 1658

[25] Frisch, M.J., Trucks, G.W., Schlegel, H.B., Scuseria, G.E., Robb, M.A., Cheeseman, J.R., Scalmani, G., Barone, V., Mennucci, B., Petersson,G.A., Nakatsuji, H., Caricato, M.X., LiHratchian, H.P., Izmaylov, A.F., Bloino, J., Zheng, G.J., Sonnenberg, L., Hada ,M., Ehara, M., Toyota, K., Fukuda, R., Hasegawa, J., Ishida, M., Nakajima,T., Honda ,Y., Kitao, O., Nakai, H., Vreven, T., Montgomery, J.A., Peralta, Jr., J.E., Ogliaro, F., Bearpark, M.J., Heyd, J., Brothers, E., Kudin, K.N., Staroverov, V.N., Kobayashi, R., Nor- 
mand, J., Raghavachari, K., Rendell, A., Burant, J.C.,. Iyengar, S.S., Tomasi, J. Cossi, M., Rega, N. Millam, ., J. M., Klene, M., Knox, J.E., Cross, J.B., Bakken, V.C., Adamo, Jaramillo, J., Gomperts, R. Stratmann, R.E., Yazyev, O., Austin, A.J., Cammi, R., Pomelli, C., Ochterski, J.W., Martin, R.L., Morokuma, K. Zakrzewski, V.G., Voth, G.A., Salvador, P., Dannenberg, J.J,. Dapprich, S., Daniels, A.D., Farkas, O., Foresman ,J.B., Ortiz, J.V., Cioslowski, J., Fox, D.J., 2004., Gaussian 03, Revision C.02, Gaussian Inc., Wallinford, CT,

[26] Prasad, O., Sinha,L., Kumar, N., Theoretical Raman and IR spectra of tegafur and comparison of molecular electrostatic potential surfaces, polarizability and hyerpolarizability of tegafur with 5-fluorouracil by density functional theory, J. Atom Mol. Sci., 2010, 1, 201. https://doi.org/10.4208/jams.032510.042010a.

[27] Kavitha, E. Sundaraganesan, N., Sebastin, S., 2010, Molecular structure, vibrational spectroscopic and HOMO, LUMO studies of 4-nitroaniline by density functional method, Ind. J. Pure Appl. Phys., 48, $20-30$

[28] Koopmans, T., 1934, Über die Zuordnung von Wellenfunktionen und Eigenwerten zu den Einzelnen Elektronen Eines Atoms Physica, 1, $104-113$.

[29] Arockia doss, M.; Savithiri, S.; Rajarajan,G.; Thanikachalam,V.; Saleem, H. Synthesis, spectroscopic (FT-IR, FT-Raman, UV and NMR) and computational studies on 3t-pentyl-2r,6cdiphenylpiperidin-4-one semicarbazone. Spectrochim Acta Part A. 2015, 148, 189-202. https://doi.org/10.1016/j.saa.2015.03.117.

[30] Arockia doss, M., Savithiri, S., Rajarajan, G., Thanikachalam, V., Anbuselvan, C., 2015, Synthesis, electronic structure investigation of 3-pentyl-2,6-di(furan-2-yl)piperidin-4-one by FT-IR, FT-Raman and UV-Visible spectral studies and $a b$ initio/DFT calculations, Spectrochimica Acta Part A, 151, 773. 